\title{
Evaluation of Anti-Plasmodial Effect of Azadrachta Indica in Plasmodium Berghi-Infected Mice
}

\author{
Nassar A.Sulaiman ${ }^{1}$, Adewole P.D and Adeleke I \\ ${ }^{1 \& 2}$ Department of Biomedical Sciences, Faculty of Basic Medical Sciences, Chemical Pathology \\ Department, Osun State University, Osogbo \\ College of Health Sciences, Ladoke Akintola University of Technology, Ogbomoso.
}

\begin{abstract}
The emergence and spread of strains of P.falciparium to most of all available antimalarial drugs constitute major problem to control of malaria. Thus there is need to search for novel, cheap, effective and safe antimalarial drugs. This study was designed to evaluate the antimalarial activities of both the leaf and the bark of Azadrachta indica. A hundred apparentelly healthy albino mice (27-30g comprising of both test and control groups) were infected intraperitoneally with Plasmodium berghei. Acute and sub-acute toxicity studies of the extracts were carried out by giving up to $800 \mathrm{mg} / \mathrm{kg}$ to apparentelly healthy non-infected mice. Weight loss, change in general behaviour and mortality were used as indicators of toxicity. Doses of 200, 600 and $800 \mathrm{mg} / \mathrm{kg} /$ day of each extract of the leaf, the bark and their combination were given orally to infected mice after three hours. Following the four-day suppressive test procedure, none of the extracts caused symptoms of toxicity at the given doses within 24hours. Each extract showed variable level of parasitaemia suppression depending on the dose. The crude aqeous extract of A.indica leaf exerted 70\% suppression at the dose of $800 \mathrm{mg} / \mathrm{kg}$. The crude aqeous extract of the bark and the leaf of A.indica swed the highest (79.68\%) suppression of parasitaemia at the dose of $800 \mathrm{mg} / \mathrm{kg}$. Furthermore, the crude aqeous extract of the bark of A.indica induced $66.32 \%$ suppression, whereas $25 \mathrm{mg} / \mathrm{kg}$ of chloroquine exerted $94.65 \%$ suppression of parasitaemia. The study showed that crude aqeous extracts of Azadrachta indicacaused strong clearance against P.berghei indicating that they contain some chemical constituents that possibly lead to antimalarial drug development.
\end{abstract}

Key Words: Evaluation, Antiplasmodial effect, Azadrachta indica, infected mice

\section{Introduction}

Malaria is a global disease that is predominant in the tropics and caused by blood parasites, Plasmodium falciparum, Plasmodium ovale, Plasmodium malariae and Plasmodium vivax (WHO, 2004). The female anopheles mosquito transmits these parasites to humans. Malaria has a great morbidity and mortality than any other infectious diseases of the world (WHO, 2006). Survey shows that $90 \%$ of the world's cases of malaria occur in sub-Saharan Africa. Nine out of ten cases of this disease occur in this region and record over one million deaths annually (Snow et al, 2004).High mortality rate is recorded in children and pregnant women (WHO, 2006), also the disease has negative impact on the economy of prevalent countries (African Summit on Roll Back Malaria, 2000). World Health Organization (WHO) estimated that malaria is endemicin Nigeriaand its mortality rate for children (0-5years) is 729 per 100, 000 children. The Federal Ministry of Health reported in April, 2004 that malaria is responsible for one out of ten deaths in pregnant women and has caused the Federal Government of Nigeria over one billion Naira annually in treating malaria (African Summit on Roll Back Malaria, 2000).Azadrachtaindica plants (Dongoyaro) are beingextensively used as traditional remedies against malaria in the tropics(FOMH, 2008). Most studies focused on efficacy of leaf extract on Plasmodium malaria infection,hence this study aimed at assessing antiplasmodial activities of A. indica(leaf and bark) on Plasmodium berghei infectedmice.

\section{Materials And Methods}

The experimental study involved using onehundred(100) mice of age range $5-7$ weeksweighing between 25 to 30 grammes. The leaves and barks of A.indica were collected from Technical College, Olorunda Local Government Osogbo, Osun State, Nigeria, while identification and authentication of the plant specimens were done at The Herbarium, Department of Botany, Obafemi Awolowo University Ile-Ife, Osun State,Nigeria.

\section{Plant Extraction}

The plant parts (leaves and barks) were air-driedseparately at room temperature under shade, and grinded into powder using an electric mill.Crude aqeous extract of the plant parts were prepared by soaking $500 \mathrm{~g}$ each in 2 litres of distilled water for 72 hours. The suspensions were shaken at interval of 24 hours. The suspensions were filtered to separate the filterate and the residue. The filtrates were dried inside Labman hot air oven at $40^{\circ} \mathrm{C} .100 \mathrm{~g}$ of each extract was dissolved in $100 \mathrm{ml}$ of deionised-distilledwater to give a stock solution 
ofl $\mathrm{g} / \mathrm{ml}$. The dosage of $200 \mathrm{mg} / \mathrm{kg}, 600 \mathrm{mg} / \mathrm{kg}$ and $800 \mathrm{mg} / \mathrm{kg}$ were preparedby seria dilution from the stocksolution for the administration to the mice.

\section{Parasite Preparation}

Chloroquine sensitive strains of Plasmodium berghei were inoculated to the sterile mice at the Medical Parasitology Laboratory of Nigeria Institute of Medical Reseach(NIMR), Yaba Lagos, Nigeria. They were then transported to the animal house of Ladoke Akintola University of Technology Osogbo, Osun State,Nigeria. $0.4 \mathrm{ml}$ of parasitized Red Blood Cells were collected from donor mice with percentage parasitemia of $25 \%$ through cardiac puncture and was diluted with $12 \mathrm{ml}$ of normal saline which resulted to $0.83 \%$ parasitemia load.0.2mlof the solution was inoculated intraperitoneally into1 1 - group (group I - XI) including positive and negative controls. Group XII - XX were used for crude toxicity test.The treatment of the animals started after three hours of infection for four days by using oral canulas.Monitoring of response of experimental animals was done on the fifth day. Blood sample was collected from tail snip of each mouse. Thin smears were prepared, fixed and stained with $10 \%$ Geimsa solution. Then, each stained slide was examined under the microscope with an oilimmersion objective lens(100x magnification power)to evaluate the percentage parasitaemia and suppressionof each extract with respect to the control groups using Greenwood and Armstrong method.. The gross physical and behavioral observation of the experimental animals was monitored at interval throughout the experimentalperiod.

\section{Results}

Acute toxicity of the experimental animals as showed in table 2 revealed that none of the four extracts caused mortality of mice within $24 \mathrm{hrs}$ up to $800 \mathrm{mg} / \mathrm{kg}$ in none-infected mice. Also, the acute toxicity study indicated that none of the four extracts caused mortality of mice within 24 hours up to $800 \mathrm{mg} / \mathrm{kg}$ in noneinfected mice (group XII - XX). Gross physical and behavioral observation of the experimental mice also revealed no visible signs of acute toxicity like lacrimation, hair erection, and reduction in their movement and feeding activities,they were physically active.

In a 4-day oral toxicity studies with $200 \mathrm{mg} / \mathrm{kg}$ and $600 \mathrm{mg} / \mathrm{kg}$ body weight of aqeous bark extract, no lethal effect was observed whilein $800 \mathrm{mg} / \mathrm{kg}$ body weight, $20 \%$ of the animals showed acute toxicity resulting in death (table 2).In $200 \mathrm{mg} / \mathrm{kg}$ of body weight of the leaf extract showed no visible signs of acute toxicity but in $600 \mathrm{mg} / \mathrm{kg}$ and $800 \mathrm{mg} / \mathrm{kg}$ of body weight of the leaf extract, $20 \%$ and $40 \%$ of the animals showed acute toxicity resulting in death respectively. In combination of the leaf and the bark extract, no lethal effect was observed in both $200 \mathrm{mg} / \mathrm{kg}$ and $600 \mathrm{mg} / \mathrm{kg}$ of body weight respectively but in $800 \mathrm{mg} / \mathrm{kg}$ of body weight, $20 \%$ of the animals shows acute toxicity resulting in death (table 2 ).

In table 3 , the aqeous bark extract ofA. indica showed $26.80 \%, 42.16 \%$ and $66.32 \%$ suppression of parasitaemia at the dose of $200 \mathrm{mg} / \mathrm{kg}, 600 \mathrm{mg} / \mathrm{kg}$ and $800 \mathrm{mg} / \mathrm{kg}$ respectively. The highest suppression of parasitaemia was observed at the dose of $800 \mathrm{mg} / \mathrm{kg}$ body weight of mice. Percentage suppression increased as extract concentrations increased. After four days treatment with the different extract doses, the mean parasitemia of the test groups for the bark were $18.30 \pm 0.24 \%, 14.45 \pm 0.20 \%$ and $8.42 \pm 0.22 \%(\mathrm{P}<0.05)$ with percentage increase in parasitemia $9.16 \%, 7.23 \%$ and $4.12 \%$ respectively while the corresponding value of the negative control group being $25.00 \pm 0.58 \%$ with percentage increase in parasitemia of $12.5 \%$ and positive control group was $1.33 \pm 0.33 \%$,with percentage suppression of $94.64 \%$ in day four.

The aqeous leaf extract of A indica showed $28 \%, 46 \%$ and $70 \%$ suppression of parasitaemia at the dose of $200 \mathrm{mg} / \mathrm{kg}, 600 \mathrm{mg} / \mathrm{kg}$ and $800 \mathrm{mg} / \mathrm{kg}$ with percentage increase in parasitemia $9.00 \%, 6.75 \%$ and $3.75 \%$ respectively (Table 3). The highest suppression of parasitaemia was observed at the dose of $800 \mathrm{mg} / \mathrm{kg}$ body weight of mice. After four days treatment with the different extract doses, the mean parasitaemia of the test groups for the bark were $18.01 \pm 0.20 \%, 13.50 \pm 0.23 \%$ and $7.30 \pm 0.29 \%(\mathrm{P}<0.05)$ respectively while the corresponding value of the negative control group being $25.00 \pm 0.58 \%$ with $12.5 \%$ percentage increase in parasitemia and positive control group was $1.33 \pm 0.33 \%$ with percentage suppression of $94.64 \%$ day fourthe combined aqeous leaf and bark extracts of $\mathrm{A}$ indica showed $38.16 \%, 50.16 \%$ and $79.68 \%$ suppression of parasitaemia at the dose of $200 \mathrm{mg} / \mathrm{kg}, 600 \mathrm{mg} / \mathrm{kg}$ and $800 \mathrm{mg} / \mathrm{kg}$ respectively. The highest suppression of parasitaemia was observed at the dose of $800 \mathrm{mg} / \mathrm{kg}$ body weight of mice. After four days treatment with the different extract doses, the mean parasitaemia of the test groups for the bark were $15.46 \pm 0.25 \%, 12.50 \pm 0.20 \%$ and $5.08 \pm 0.22 \%(\mathrm{P}<0.05)$ with percentage increase in parasitemia $7.73 \%, 6.23$ and $2.54 \%$ respectively while the corresponding value of the negative control group being $25.00 \pm 0.58 \%$ with $12.5 \%$ percentage increase in parasitemia and positive control group was $1.33 \pm 0.33 \%$ with percentage suppression of ative and positive control groups $.64 \%$ day four. The highest suppression of parasitaemia was observed at the dose of $800 \mathrm{mg} / \mathrm{kg}$ body weight of mice..There is synergistic effect in the leaf and the bark extract making it to have the highest concentration.Also, the leaf showed the higher suppression of the parasite than the bark.In the negative control, there is significant increase of parasitaemia in the animals after 4 days while the parasite is almost cleared from 
the system of the animals.Generally, The mean parasitaemia of aqeous extracts of the leaf of A. Indicaat $200 \mathrm{mg} / \mathrm{kg}, 600 \mathrm{mg} / \mathrm{kg}$ and $800 \mathrm{mg} / \mathrm{kg}$ respectivelyare significantly high compare with the mean of the negative control $(25.00 \pm 0.58)(\mathrm{P}<0.05)$, hence, there is significant decrease in the percentage parasiteamia among the infected mice treated with leaf extract as showed in figure 1.

\begin{tabular}{|c|c|c|c|c|c|c|c|c|}
\hline \multirow[b]{2}{*}{ Dose (mg/kg) } & \multicolumn{3}{|c|}{ Extracts + Parasite } & \multicolumn{3}{|c|}{ Extracts + No Parasite } & \multicolumn{2}{|c|}{ Controls + Parasite } \\
\hline & Barks & Leaf & Both & Barks & Leaf & Both & Positive & Negative \\
\hline 200 & I & IV & VII & XII & $\mathrm{XV}$ & XVIII & & \\
\hline 600 & II & $\mathrm{V}$ & VIII & XIII & XVI & XIX & & \\
\hline 800 & III & VI & IX & XIV & XVII & $\mathrm{xX}$ & & \\
\hline $25(\mathrm{CQ})$ & & & & & & & $\mathrm{x}$ & \\
\hline $\mathrm{D} / \mathrm{H}_{2} \mathrm{O}$ & & & & & & & & $\mathrm{XI}$ \\
\hline
\end{tabular}

TABLE 2: Acute Toxicity Test (LD50) of the Extracts on the Experimental Mice

\begin{tabular}{lccc} 
GROUP & INITIAL & No of death recorded & \% Death \\
\hline $\mathrm{XII}$ & 5 & 0 & 0 \\
$\mathrm{XIII}$ & 5 & 0 & 0 \\
$\mathrm{XIV}$ & 5 & 1 & 20 \\
$\mathrm{XV}$ & 5 & 0 & 0 \\
$\mathrm{XVI}$ & 5 & 1 & 20 \\
$\mathrm{XVII}$ & 5 & 2 & 40 \\
$\mathrm{XVIII}$ & 5 & 0 & 0 \\
$\mathrm{XIX}$ & 5 & 0 & 0 \\
$\mathrm{XX}$ & 5 & 1 & 20 \\
\hline
\end{tabular}

Table 3;ACTIVITY OF DIFFERENT EXTRACTS OF A. INDICA ON P. BERGHEI INFECTED MICE

\begin{tabular}{|c|c|c|c|c|c|c|c|}
\hline Conc. & & $\%$ & \% suppressio & & Mean & & \\
\hline (Mg/kg) & Group & Parasitemia & Leaf $B c$ & Bark Bark+ & Leaf & ( \pm SEM) P-value & \\
\hline \multirow[t]{3}{*}{200} & 1 & 9.15 & - & 26.80 & - & $18.30 \pm 0.24$ & $<0.05$ \\
\hline & IV & 9.00 & 28.00 & - & - & $18.01 \pm 0.20$ & $<0.05$ \\
\hline & VII & 7.73 & - & - & 38.16 & $15.46 \pm 0.25<0.05$ & \\
\hline \multirow[t]{3}{*}{600} & " & 7.23 & - & 42.16 & - & $14.15 \pm 0.20$ & $<0.05$ \\
\hline & $\mathrm{v}$ & 6.75 & 46.00 & - & - & $13.50 \pm 0.23$ & $<0.05$ \\
\hline & VIII & 6.23 & - & - & 50.16 & $12.45 \pm 0.20$ & $<0.05$ \\
\hline \multirow[t]{3}{*}{800} & III & 4.12 & - & 66.32 & $\cdot$ & $8.42 \pm 0.22$ & $<0.05$ \\
\hline & $\mathrm{vI}$ & 3.75 & 70.00 & - & - & $7.50 \pm 0.29$ & $<0.05$ \\
\hline & $\mathrm{IX}$ & 2.54 & - & - & 79.68 & $5.08 \pm 0.22$ & $<0.05$ \\
\hline \multirow[t]{2}{*}{25 (CQ) } & $\mathrm{x}$ & 0.67 & & 94.64 & & $1.33 \pm 0.33$ & $<0.05$ \\
\hline & $\mathrm{xI}$ & 12.50 & & 0.00 & & $25.00 \pm 0.58$ & \\
\hline
\end{tabular}

$\mathrm{CQ}=$ Chloroquine

${ }^{*} \mathrm{p}$-value $<0.05$ considered significant when compared with negative control (group XI) 


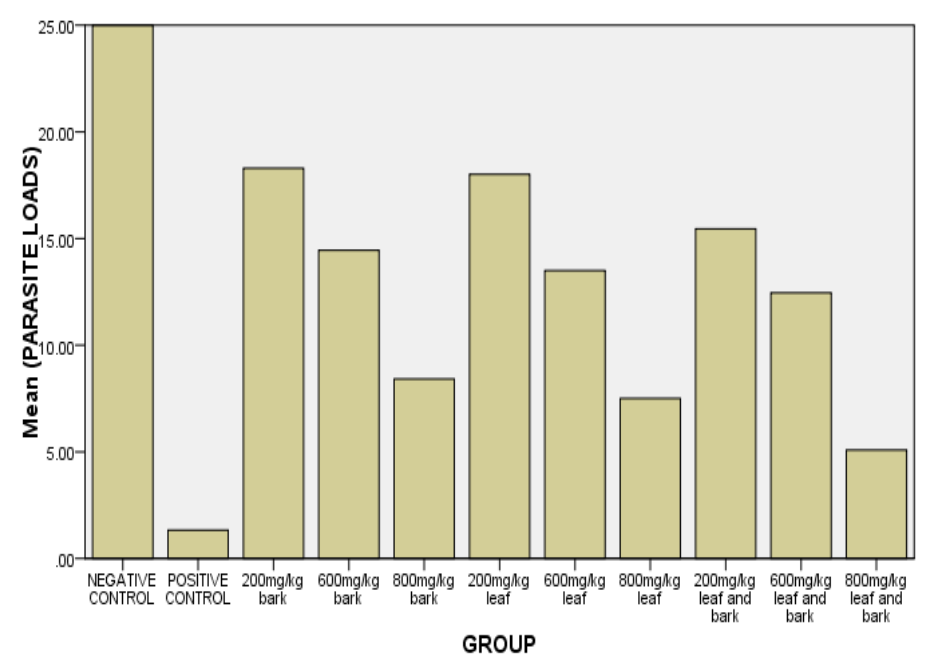

Figure 1:Effect of extract on parasitae

\section{Discussion}

In this study,aqeous crude extract of the leaf and the bark of Azadrachta indicawere investigated in P.berghie mouse model. The P.berghei mouse model has been widely used as a preliminary test for the in vivo activity of potential antimalaria agents. This is because the model provides a preclinical indication of in vivo potential bioactivity as well as possible toxicity of the sample tested.Significant decrease in the percentage parasiteamia among the infected mice treated wih leaf extract in this present study may be attributed to the presence of Azadrachitin,quercetin,flavonoid,gedunin, $\beta$-sitosterol and nimbolide which may cause inhibition of malaria parasites. This finding was in agreement with the previous studies carried out by Isah et al(2003) which demonstrated that A. indica leaf extracts possess in vitro inhibitory activity on Plasmodium falciparum asexual stages. The decrease in the percentage parasiteamia of the infected mice treated with bark of A. Indica is in line with the previous study by Khkai(1982)which showed that antimalarial activities of a tablet suspension of the bark and leaf of Neem exhibited high prophylactic, moderate suppressive, and a very minimal curative schizonticidal effect in experimental mice. The means of the percentage parasiteamia among the infected mice that took aqeous extract bark of A. indicaat different concentrations are significantly decreased compared with the mean of the negative control of mean may be attributed to presence of additional bio-active compounds which agreed with previous study that shows that Neem leaf extract substantially increases the state of oxidation in red blood cells, preventing normal development of the malaria plasmodia..Also,our present studyis inline with Biswas et al 200 where higher suppression rate was obtained at $70 \%$ concenteration of the aqueous extract.In this study, combination of both the leaf and the bark extract show highest suppression may probably due to presence of substance that serves as an adjuvant in bark extract

The in vivo activities of Azadrachta indica in this study shows that the plant still serve as antiplasmodial compounds, this necessitates further work and justifies the use of the plant in Nigeria ethnomedicine.The present study showed high reduction inparasitaemia.It is recommended that the active ingredients need to be identified and quantified.. More efforts are required to formulate this potentially effective substance in manner that minimize its adverse effects and optimise its benefits in prevention and treatment. There should be writing regulations to cover standard of potency of A.indica as the mix of active ingredient vary with the sample's age, the locality where it was grown, the genes of the tree it came from and the method of extraction. Accurate information on toxicity dosage and drug interactions. It is important to work closely with community traditional medicine users whose cure-malaria approach to the use of A.indica tree extract with lack of stardidization with regards to dosage, may be more to damage the evolving credibility of this novel plant than promoting its strong potentials as a mainstream anti-malaria medication. The crude extract should be further fractionated and tested for their activity against P.falciparum.. 


\section{Refrences}

[1]. WHO (2004).Strategies framework for malaria prevention and control during pregnancy in the African region.Volume 01.Congo Brazzaville: WHO Regional office for Africa.

[2]. World Health Organization (2006): Guideline for the treatment of malaria (WHO/HTM/MAL/2006.1108)www.who.int/malaria/docs/TreatmentGuidline2006.pdf

[3]. Snow R.W; Trape J.F, Marsh K. (2004).The past, present and future of childhood malaria mortality in Africa.Trends in parasitology, 17,593-597.

[4]. World Health Organization(2006): Guideline for the treatment of malaria (WHO/HTM/MAL/2006.1108)www.who.int/malaria/docs/TreatmentGuidline2006.pdf

[5]. African Summit on Roll Back Malaria, author.Summit on Roll Back Malaria Abuja, Nigeria.Abuja MalsumIntbrief. 2000 Mar 2;

[6]. African Summit on Roll Back Malaria, author.Summit on Roll Back Malaria Abuja, Nigeria.Abuja MalsumIntbrief. 2000 Mar 2;

[7]. FOMH (2008).Malaria control in Nigeria;A strategy for behaviour change communication in the roll back malaria programme in Nigeria.Publication of Roll Back Malaria Secretariat,National Malaria Control Programme,Department of Department of Public Health,Federal Ministry of Health Abuja.

[8]. Kakai Tokkyo Koho, J.P. (1982).Research journal on pharmaceutical, biological and chemical properties of neem. Chem. Abstr., $\mathbf{1 0 0 , 9 1 3 5 0 .}$

[9]. MacKinnon S; Durst T; Arnason J.T, et al.(1997) Antimalarial activity of tropical Meliaceae extracts and gedunin derivatives. J Nat Prod; 60: 336-341.

[10]. Ang K.K; Holmes M..J;Higa T;Hamann MT;Kara U.A.K(2000).In vitro antimalarial activity of Beta-Carboline Alkaloid manzamine A.Antimaicrobial agents andChemotherapy,44(6),1645-1649

[11]. Isah A.B; Ibrahim Y.K.E; Iwalewa E.O. (2003).Evaluation of the antimalarial properties and standardization of tablets of Azadirachta indica (Meliaceae) in mice. Phytother Res; 17: 807-810. 